\title{
THE 2020 REFORM OF THE WATER AND SANITATION SERVICES SECTOR IN BRAZIL
}

\author{
CARLOS MOTTA NUNES, \\ Brazil's National Water and Sanitation Agency (Brasília, Brazil) \\ ALEXANDRE ANDERAOS, \\ Brazil's National Water and Sanitation Agency (Brasília, Brazil) \\ CINTIA LEAL MARINHO DE ARAUJO, \\ Brazil's National Water and Sanitation Agency* (Brasília, Brazil)
}

https://doi.org/10.21684/2412-2343-2021-8-2-66-88

With over 100 million people without access to sewage collection and treatment and over 35 million lacking access to piped drinking water, the water and sanitation services (WSS) sector in Brazil ranks last among all the infrastructure sectors. Despite previous efforts to reach universal coverage, the gap remains wide. In order to reduce this gap, the Brazilian Parliament approved the reform of the WSS sector in July 2020. This paper examines the state of the water and sanitation services in Brazil before 2020 as well as the potential effects of the recently approved reform. It demonstrates that the sector's primary issues are the fragmented institutional arrangements and regulations, the low levels of investments by the public sector, including those made by State-owned water companies, and the barriers to entry for the private sector. The paper also discusses the new provisions included in the reform designed to remedy those issues. The authors believe that the reform has the potential to promote significant changes in the structure of the WSS towards providing a universal and equitable service in Brazil, but at a slower pace than the reformers anticipated.

Keywords: water; sewage; sanitation; water and sanitation services; regulation; legal reform; regionalization.

\footnotetext{
The views and opinions expressed in this paper are those of the authors and do not necessarily reflect the official policy or position of Brazil's National Water and Sanitation Agency.
} 
Recommended citation: Carlos Motta Nunes et al., The 2020 Reform of the Water and Sanitation Services Sector in Brazil, 8(2) BRICS Law Journal 66-88 (2021).

\section{Table of Contents}

\section{Introduction}

\section{The WSS Sector in Brazil - A Historical Perspective and the Situation} Before the 2020 Reform

2. The New Provisions of the Recent Water and Sanitation Law 2.1. Law $14.026 / 2020$ - The Reform of the Water and Sanitation Services Sector in Brazil

3. Regulation and Role of Brazil's National Water and Sanitation Agency 3.1. Brazil's National Water and Sanitation Agency (ANA, in the Portuguese Acronym)

\section{Is That Going to Work? A Critical Analysis of the WSS Sector Reform} Conclusion

\section{Introduction}

The low level of water and sanitation services (WSS) in Brazil, in terms of quality and availability, remains one of the major problems the country still faces, with consequences for public health, the environment, tourism and the standard of living, particularly in large cities, affecting thousands of people across the country.

With more than 100 million people without access to sewage collection and treatment and more than 35 million lacking access to piped drinking water, the WSS sector in Brazil is ranked last among all the infrastructure sectors.

In terms of water security, the World Economic Forum (WEF) ranks Brazil $78^{\text {th }}$ out of 141 participating countries in the research, in its Global Competitiveness Report 2019.

Many efforts have been made in recent decades to achieve the universalization of this essential public service, with particular emphasis on Law 11.445/2007, also known as the "National Water and Sanitation Law," which established the sector's current legal framework.

That legislation laid the groundwork for the country's WSS to become universal. Despite some significant advances, the level of investments has been lower than

Klaus Schwab, Global Competitiveness Report 2019: How to End a Lost Decade of Productivity Growth, World Economic Forum (October 2019) (Apr. 15, 2021), available at https://www.weforum.org/reports/ how-to-end-a-decade-of-lost-productivity-growth. 
what was hoped for at the time the law was passed, and the goal of universalization remains a long way off, especially in the area of sewage collection and treatment.

Some of the major challenges of the WSS in Brazil have been a lack of standardization and regulatory effectiveness, lack of competition and attractiveness for the private sector, and, as a result, a lack of private investments.

In order to improve the structural conditions of WSS in the country, the Federal Government established a Task Force in 2016 to propose a reform of the sector. The Task Force identified the following as the primary issues confronting the sector: a fragmented regulatory framework, the dispersion of policy functions among government bodies, the public sector's limited financial capacity to make the necessary investments and barriers to entry for the private sector to provide services.

The Task Force then presented a proposal for the reform of the WSS sector focusing on the issues just highlighted. Before its final approval by the Brazilian Parliament, there were two attempts to reform the sector.

The first attempt was made on 6 July 2018 when the Federal Government issued Provisional Presidential Decree ${ }^{2} 844 / 2018 .^{3}$ This proposal was met with great opposition from several interest groups and lost its effectiveness on 19 November 2018 because it was not timely confirmed by the Parliament.

On 27 December 2018, in the last days of the term of then President Michel, the Presidential Decree $868 / 2018^{4}$ was published containing nearly the same content as the previous one. The Provisional Presidential Decree also lost its effectiveness on 3 June 2019 as a result of the lack of agreement between the government and the opposition.

Finally, after a lengthy debate in the Brazilian Parliament, lawmakers approved the Bill n. 4.162/2019, which was sanctioned by President Jair Bolsonaro after he presented seventeen vetoes to the text, as Law 14.026/2020. This law represents a major reform in the WSS sector in Brazil and is expected to pave the way for the universalization of services.

This paper describes the current state of the WSS in Brazil, the new provisions brought about by the reform approved by the Parliament and the potential impact of the reform. The paper is divided into four sections. Section 1 provides a historical perspective and the current status of the WSS in Brazil as well as the legal framework prior to the approval of Law 14.026/2020. Section 2 highlights the main provisions brought about by the sector's reform, while Section 3 focuses on the changes in the regulatory framework. Section 4 then discusses the major challenges that must be

\footnotetext{
In Brazil, the President of the Republic can issue a provisional presidential decree in situations of extreme relevance and urgency. A legislative measure of this nature must be voted and confirmed by the Parliament within 120 days, during which it can accept or reject the decree, even if tacitly, in the latter case, by the expiry of the period.

3 Brasil, Medida Provisória n 844, 2018.

4 Brasil, Medida Provisória n 868, 2018.
} 
overcome in order for this reform to work as intended. Finally, some conclusions are drawn on the topics covered the paper.

It is worth noting that in Brazil, the term "basic sanitation" refers to water supply and sanitation services, as well as urban solid waste management and urban storm water management. Law 14.026/2020, also known as the "New Basic Sanitation Law," refers to these four services; however, only water and sanitation services will be addressed in this paper.

\section{The WSS Sector in Brazil - A Historical Perspective and the Situation Before the 2020 Reform}

Water and sanitation services in Brazil are provided primarily by the public sector. Out of 5,570 municipalities in the country, $70 \%$ are served by State-owned water companies, $25 \%$ by municipal public companies and only $5 \%$ by private operators. In terms of population served, State-owned companies serve $69 \%$ of the population, municipal services serve $21 \%$ and private operators serve about $10 \%$ of Brazilians.

In terms of service coverage, the Brazilian population still faces major obstacles in gaining access to WSS. According to the National Water and Sanitation Information System (SNIS) (2018), 34 million people (16.4\% of the population), roughly the population of Canada, still do not have access to drinking water. Furthermore, sewage collection systems do not serve 100 million Brazilians (46.8\% of the population), which is nearly equivalent to the combined populations of France and Spain, and only $46.3 \%$ of the collected sewage is treated before being discharged into the environment.

Aside from the low coverage of the WSS in Brazil, there is a high rate of water loss in the distribution systems. The amount of resources invested in the sector is still insufficient to expand coverage, reduce losses and improve the quality of service to the population. This amount, for example, was only $0.18 \%$ of GDP in 2016 . The total investment made in the sector, BRL 11.33 billion, is far less than the BRL 40 billion annual investment estimated by the National Basic Sanitation Plan (PLANSAB) as being required for universalization by 2033 .

A historical perspective may help in understanding how this situation came about.

In the historical context, several efforts were made in the second half of the $20^{\text {th }}$ century to alleviate the problems related to WSS, beginning with the Economic Action Program (PAEG), during the military regime between 1964 and 1968, which expanded service coverage, followed by the establishment of the National Sanitation Plan (PLANASA) in 1967, financed by the National Housing Bank (NHB). Another significant initiative was the reform of the federal public administration's institutional framework, which laid the groundwork for the decentralization of public services and facilitated the transition from municipal to State-owned water companies. 
PLANASA was a landmark in the story of WSS ${ }^{5}$ in Brazil. It was conceived as a national policy with the goal of providing WSS on a large scale throughout the country while encouraging the formation of State-owned water companies. As a result, each State in Brazil would have its own water company responsible for providing services across a large portion of its territory. PLANASA also created a centralized administrative and financial structure at the $\mathrm{BNH}$ which was in charge of setting up tariffs for those State-owned water companies.

In terms of water supply, the plan progressed well up to the mid-1980s. Little progress was made, however, in terms of sanitation. The dissolution of the NHB in 1985 , in the context of the country's fiscal crisis of that period, marked the end of WSS policies in Brazil. Following that, the roles related to the financing of WSS were transferred to Caixa Econômica Federal, a Brazilian public bank.

The institutional vacuum caused by the termination of PLANASA was only effectively broken in 2007 with the approval of Law $11.445 / 2007,{ }^{6}$ which established the legal framework for water and sanitation services in the country, representing a significant milestone in the country's provision of this public service. To summarize, Law 11.445/2007:

- established concepts and principles for the provision of WSS;

- allowed municipalities to delegate the organization, regulation, inspection and provision of services;

- made it mandatory to sign a contract when WSS are not provided by the municipalities themselves;

- defined the requirements for the validity of those contracts;

- outlined the content of WSS master plans, at the national, regional and municipal levels;

- established the need for regulation and defined the subjects to be regulated, including the technical, economic and social aspects of service provision.

The clear separation of the various WSS actors' roles in planning, regulation and service-provision activities was one of the major advances brought about by Law $11.445 / 2007$.

In terms of planning, the law established three geographical levels and institutions responsible for developing and implementing WSS master plans: federal (National Basic Sanitation Plan), regional (Regional Basic Sanitation Plan) and municipal (Municipal Basic Sanitation Plan). At the federal level, the Master Plan establishes objectives, goals and guidelines that must be followed at the regional and municipal levels, depending on whether the service is provided at the municipal or regional level.

\footnotetext{
Rodrigo Luiz Nascimento Lobo, O saneamento básico no Brasil: um estudo sobre a distribuição de investimentos públicos federais nas cidades médias entre 2004 e 2013, Dissertação (2016) (Apr. 15, 2021), available at http://objdig.ufrj.br/42/teses/859334.pdf.

6 Brasil, Lei no 11.445, 2007.
} 
The basic sanitation plans would be approved by acts of the owners, According to Law $11.445 / 2007$ they shall be prepared the basis of technical studies and must be compatible with the respective river basin master plans as well as with the master plans of the municipalities in which they are located, or with the integrated urban development plans of the regional units they cover.

In terms of regulation, Law 11.445/2007 made it mandatory for a municipality to delegate the regulation of the services to a regulatory agency, but allowed for various institutional models: the municipality can create its own municipal agency to regulate service provision; alternatively, it can delegate regulation to a State agency, or it can delegate to an agency formed by a group of municipalities. ${ }^{7}$ As a result, the country now has over seventy subnational regulatory agencies. More information on the outcomes of this regulatory framework will be below.

Finally, regarding service provision, there is the issue of ownership. In Brazil, ownership of the services belongs to the municipalities and they can provide the WSS themselves or delegate through concessions contracts to the private sector, or through public/public contracts ${ }^{8}$ to State-owned water companies. Table 1 shows the distribution of the service providers in the country.

Table 1. WSS in each Brazilian Region according to the type of provider

\begin{tabular}{|l|c|c|c|c|}
\hline \multicolumn{5}{|c|}{$\begin{array}{r}\text { Water and Sanitation Service providers in Brazil } \\
\text { (number of municipalities served) }\end{array}$} \\
\hline Region & State Company & $\begin{array}{c}\text { Municipal } \\
\text { Service }\end{array}$ & $\begin{array}{c}\text { Private } \\
\text { Company }\end{array}$ & Total \\
\hline North & 225 & 56 & 77 & 358 \\
\hline Northeast & 1,488 & 304 & 4 & 1,796 \\
\hline Southeast & 1,066 & 669 & 50 & 1,785 \\
\hline South & 857 & 318 & 12 & 1,187 \\
\hline Midwest & 294 & 92 & 37 & 423 \\
\hline Total & 3,930 & 1,439 & 180 & 5,549 \\
\hline
\end{tabular}

Source: SNIS 2018 (data from 5,549 municipalities of the 5,570 existing in Brazil)

One critical issue is that Law 14.026/2020 allowed these public/public contracts to be signed without going through a bidding process, and thus creating a barrier to entry for the private sector. Additionally, those contracts are very incomplete when compared to concession contracts. Many of them do not include clauses on goals

\footnotetext{
7 In Brazil, these agencies are called "inter-municipal agencies."

8 This type of contract is called "program contract" in Brazil.
} 
and about the quality of the services provided, and they do not allocate the risks between the parties. Because these State-owned companies are larger institutions than most municipalities they serve, even when the quality of the service is very poor, it is difficult for municipalities to take back the provision of the services. This is because of the asymmetry of information on the value of the assets built by the State-owned companies. That is to say, the municipalities do not know how and do not have the means to calculate the fair value of indemnities for unamortized assets. Moreover, in many cases, when the value is correctly calculated, the municipality cannot afford the indemnity.

After the termination of PLANASA in the mid-1980s, many of those Stateowned water companies faced financial difficulties. This was caused mainly by the dissolution of the NHB, which reduced loans to the sector as well as by failures in the corporate governance of those companies, which were administered by political appointees without the skills necessary to hold executive positions. Only a few of those companies, such as SABESP (State-owned Water Company of the State of Sao Paulo, with more than 27 million clients), were able to restructure their governance and have the financial capacity to make new investments. In fact, out of twenty-five State-owned water companies that still exist today, only three of them have their stocks traded on the Stock Exchange: SABESP, COPASA (Minas Gerais State-owned Water Company) and SANEPAR (Parana State-owned Water Company).

The result of this whole situation is that WSS coverage rates in Brazil are still very low when compared to other infrastructure sectors. While electricity and telecommunications reach almost the entire country's population, the water and sanitation sector lags behind. Tables 2 and 3 show the population served in each Region of the country.

Table 2. Water supply coverage by Region

\begin{tabular}{|l|l|l|l|l|l|l|}
\hline Region & $\begin{array}{l}\text { Total } \\
\text { Population }\end{array}$ & $\begin{array}{l}\text { Total } \\
\text { Population } \\
\text { Supplied }\end{array}$ & $\begin{array}{l}\text { Total } \\
\text { Population } \\
\text { Supplied } \\
(\%)\end{array}$ & $\begin{array}{l}\text { Urban } \\
\text { Population }\end{array}$ & $\begin{array}{l}\text { Urban } \\
\text { Population } \\
\text { Supplied }\end{array}$ & $\begin{array}{l}\text { Urban } \\
\text { Population } \\
\text { Supplied } \\
(\%)\end{array}$ \\
\hline North & $15,472,806$ & $8,827,538$ & $57.1 \%$ & $12,069,203$ & $8,399,130$ & $69.6 \%$ \\
\hline Northeast & $54,476,270$ & $40,428,336$ & $74.2 \%$ & $40,589,494$ & $35,983,001$ & $88.7 \%$ \\
\hline Southeast & $87,079,465$ & $79,205,226$ & $91.0 \%$ & $81,158,373$ & $77,828,232$ & $95.9 \%$ \\
\hline South & $29,469,490$ & $26,579,702$ & $90.2 \%$ & $25,254,069$ & $24,889,685$ & $98.6 \%$ \\
\hline Midwest & $15,716,477$ & $13,984,680$ & $89.0 \%$ & $14,096,113$ & $13,537,928$ & $96.0 \%$ \\
\hline Brazil & $202,214,508$ & $169,025,482$ & $83.6 \%$ & $173,167,252$ & $160,637,976$ & $92.8 \%$ \\
\hline
\end{tabular}

Source: SNIS 2019 
Table 3. Sanitation coverage by Region

\begin{tabular}{|l|l|l|l|l|l|l|}
\hline Region & $\begin{array}{l}\text { Total } \\
\text { Population }\end{array}$ & $\begin{array}{l}\text { Total } \\
\text { Population } \\
\text { Supplied }\end{array}$ & $\begin{array}{l}\text { Total } \\
\text { Population } \\
\text { Supplied } \\
(\%)\end{array}$ & $\begin{array}{l}\text { Urban } \\
\text { Population }\end{array}$ & $\begin{array}{l}\text { Urban } \\
\text { Population } \\
\text { Supplied }\end{array}$ & $\begin{array}{l}\text { Urban } \\
\text { Population } \\
\text { Supplied } \\
(\%)\end{array}$ \\
\hline North & $15,472,806$ & $1,623,356$ & $10.5 \%$ & $12,069,203$ & $1,609,342$ & $13.3 \%$ \\
\hline Northeast & $54,476,270$ & $15,256,503$ & $28.0 \%$ & $40,589,494$ & $14,712,339$ & $36.2 \%$ \\
\hline Southeast & $87,079,465$ & $68,928,444$ & $79.2 \%$ & $81,158,373$ & $67,885,823$ & $83.6 \%$ \\
\hline South & $29,469,490$ & $13,310,783$ & $45.2 \%$ & $25,254,069$ & $13,105,339$ & $51.9 \%$ \\
\hline Midwest & $15,716,477$ & $8,312,487$ & $52.9 \%$ & $14,096,113$ & $8,209,624$ & $58.2 \%$ \\
\hline Brazil & $202,214,508$ & $107,431,573$ & $53.1 \%$ & $173,167,252$ & $105,522,467$ & $60.9 \%$ \\
\hline
\end{tabular}

Source: SNIS 2019

From Tables 2 and 3, one may conclude that the challenges achieving the goal of universalization of services is huge, especially in the poorest Regions of the country, namely North Region, where the Amazon forest is located, and in the Northeast Region, where most of the land experiences a semi-arid climate, and where severe droughts are frequent.

The next section will therefore address the changes brought about by the 2020 reform of the WSS sector in Brazil that are aimed at reversing the present direction of low coverage and poor quality of services.

\section{The New Provisions of the Recent Water and Sanitation Law}

The previous section set the stage for the need to reform the water and sanitation services sector in Brazil. It highlighted the low level of the services, especially in terms of coverage of sanitation. It showed that most of the services are provided by Stateowned water companies that benefit from a legal arrangement that allows them to sign contracts with municipalities without going through a bidding process, and thus creating barriers to entry for private operators. It was also pointed out that this situation leads to a low level of investments, setting in motion the vicious cycle where the low level of investments leads to a low level of services that, in its turn, leads to a lack of confidence on the part of the population, which opposes any tariff increases, reducing, even more, the investment capacity of the service provider.

Giambiagi' shows that the WSS sector lags behind in terms of investments when compared to other infrastructure sectors in Brazil. The electricity and telecommunications

9 O Futuro do Brasil (Fabio Giambiagi ed., 2021). 
sectors, which are almost completely privatized, have higher levels of investments than the WSS sector. In its turn, transportation, which also still has huge gaps in service coverage, and has seen the participation of private operators increase in recent decades, has also received more investment than the WSS sector.

Table 4. Evolution of investment rates by sector, in \% of GDP

\begin{tabular}{|l|c|c|c|c|c|c|}
\hline Sector & $1970-1980$ & $1981-1990$ & $1991-2000$ & $2001-2010$ & $2011-2016$ & 2017-2018 \\
\hline Telecom & 0.93 & 0.38 & 0.71 & 0.63 & 0.47 & 0.45 \\
\hline Electricity & 2.47 & 1.26 & 0.68 & 0.57 & 0.68 & 0.65 \\
\hline WSS & 0.53 & 0.20 & 0.15 & 0.17 & 0.19 & 0.20 \\
\hline Transportation & 2.36 & 1.26 & 0.57 & 0.59 & 0.85 & 0.47 \\
\hline Total & 6.29 & 3.10 & 2.11 & 1.96 & 2.19 & 1.77 \\
\hline
\end{tabular}

Source: Giambiagi (2021)

Therefore, the main objective of the reform of the WSS sector in Brazil is to achieve universalization of services, aiming to reach $99 \%$ coverage of water supply and $90 \%$ coverage of sanitation by the year 2033. These are ambitious goals and the subject of discussion ahead.

The universalization of water and sanitation services would provide enormous direct and indirect benefits to the country. According to Trata Brasil, ${ }^{10}$ these benefits are expected to reach up to BRL 1.5 trillion across the country in twenty years, with direct benefits of BRL 820 billion generated from investment in the sector, such as the creation of jobs and income and tax collection, and with indirect benefits of BRL 670 billion from the reduction of losses associated with externalities, such as reduced health costs, increased productivity, real estate valuation and expansion of tourism.

\subsection{Law $14.026 / 2020$ - The Reform of the Water and Sanitation Services Sector in Brazil}

Law 14.026/2020 was sanctioned by President Jair Bolsonaro on 15 July 2020. This law reformed the WSS sector in Brazil and updated seven different laws that make up the legal framework for the sector. These changes have the primary objective of improving the business environment for investments in the sector by establishing a more secure regulatory framework. It also set provisions to improve water resources management, but it is not the focus of this paper.

10 Trata Brasil, Saneamento é Saúde (2017) (Apr. 15, 2021), available at www.tratabrasil.org.br/datafiles/ estudos/panorama-dos-pmbs/press-release.pdf. 
In summary, the legal changes brought about by the reform can be structured on four pillars that consolidate the main advances in the new legal framework. They are: improvements in the regulatory framework; regionalization of the provision of services; standardization of services provision contracts; and removal of barriers to entry to the private sector.

The first pillar, improvements in the regulatory framework, aims to reduce the regulatory risks in the country. As mentioned earlier, there are more than seventy subnational regulatory agencies in the country, each one with its own set of regulations and procedures, and different levels of capacity and institutional maturity. Therefore, the reform establishes that a federal agency, the National Water and Sanitation Agency (ANA) will publish standard guidelines for the regulation of the services. More details on this role are presented in the next section.

The second pillar corresponds to the provisions in the law that incentivize regionalization of the services. WSS require large investments, and they benefit from economies of scale. Therefore, the process involves the aggregation of municipalities into WSS regions in order to benefit from those economies of scale, aiming at universalization and the financial feasibility of the provision of the services. The regionalization also motivates the harmonization of planning, regulation and enforcement of the legislation.

Studies point out that the aggregation of services into regions provides greater efficiency through economies of scale and cost-sharing. Regionalization can reduce management expenses, and operational and billing costs. It also benefits from a higher technical capacity of personnel and knowledge exchange, greater access to finance, and better conditions to attract private-sector investments. ${ }^{11}$

To foster regionalization, Law 14.026/2020 restricts access to federal funds to municipalities that do not join a WSS region. Therefore, those municipalities will not be allowed to receive government grants or loans from the Federal Government to make new investments in the provision of services. It is a very impactful provision, as it brings in the "spending powers" of the Federal Government, which is responsible for almost all the funding available to the sector in the country.

The standardization of contracts, the law's third pillar, has three main objectives: establish the goals of universalization; reduce regulatory and legal risks; and reduce the costs of compliance.

As already mentioned, most of the contracts for the provision of services do not set goals for the universalization of services. Therefore, the reform establishes that all the contracts, even those already signed, shall include clauses requiring the achievement of the universalization goals of $99 \%$ of the population with adequate

11 Gustavo Ferro, Literature Review: Global Study on the Aggregation of Water Supply and Sanitation Utilities, The World Bank (August 2017) (Apr. 15, 2021), available at https://documents1.worldbank. org/curated/en/962151503628572004/pdf/1 19097-WP-PUBLIC-P159188-35p-ADD-SERIES-lit-review24-8-2017-12-18-52-W.pdf. 
access to drinking water and $90 \%$ of the population with sewage collection and treatment by 31 December 2033.

The second and third objectives of standardization of contracts are to reduce regulatory and legal risks and reduce the costs of compliance. Law 14.026/2020 establishes a set of clauses stating that all contracts shall contain and seek to converge those public/public contracts between Municipalities and State-owned companies with concession contracts. The law bestows upon ANA the responsibility for drafting standard contracts for the provision of water and sanitation services, in the case of concession contracts and public/public contracts alike, and they must contain the essential clauses of the concession contracts, including, but not limited, to:

- universalization goals and service efficiency;

- possible sources of alternative, complementary or accessory revenue;

- methodology for calculating any indemnity related to reversible assets not amortized at the time of termination of the contract;

- risk-sharing between the parties.

Furthermore, the contracts shall be as complete as possible so as to reduce the discretionary powers of the subnational regulatory agencies. As will be detailed in the next section, some agencies are too small and do not have the capacity to properly regulate the provision of the services. Others are not independent of the government, increasing the risks of short-term political decisions. Therefore, the standardization of contracts is expected to reduce the political and regulatory risks as well as the cost of compliance for large operators that provide the services in many cities and regions.

The last pillar of the new law is the attempt to remove barriers to entry for the private sector. As presented earlier, private operators provide services in only $5 \%$ of all Brazilian municipalities. It was also pointed out that this is mainly due to those public/public contracts between State-owned water companies and municipalities that allow the contracts to be signed without going through a bidding process.

Law $14.026 / 2020$ now requires that any new contract for the provision of services needs to be preceded by a bidding process. It states that the current public/public contracts are still valid but cannot be renewed at the end of their term. When terminated, a bidding process shall be carried out and the winner will sign a concession contract, even if it is a State-owned water company.

Nevertheless, the reform also brings about a number of provisions intended to reduce the participation of State-owned water companies that will not be able to achieve the goals of universalization by 2033. By 31 March 2022, those companies must provide evidence that they have the means to make the investments necessary to achieve universalization. They must be able to show that they can generate sufficient cash flow to operate the services adequately and make those investments. If the company is not able to provide evidence of its financial health, its contract will be terminated, and a bidding process must be carried out to choose another 
service provider. This requirement is another way of making public service providers' current contracts compatible with private ones, as the latter undergo this capacity assessment at the time of bidding. On the other hand, if the company shows that it has the capacity to make the investments, its contract needs to be amended, including the clauses that converge public/public contracts to the concession ones mentioned before for the new contracts.

From the standard guidelines and contracts to be drafted by ANA, through the need to comply with the requirement of a bidding process, all of these provisions aim at increasing the level of private investments in a country facing fiscal deficits that will not allow large public expenditures in the next few years.

\section{Regulation and Role of Brazil's National Water and Sanitation Agency}

The history of the regulation of the WSS sector in Brazil started before the approval of the Water and Sanitation Law in 2007. For instance, tariff regulation, as mentioned before, was carried out by the National Housing Bank from the beginning of PLANASA until the dissolution of the bank in 1985.

The first WSS regulatory agencies were created in 1997 and, until 2007 (the year of approval of the Water and Sanitation Law), there were already twenty-one agencies in the country. Law 11.445/2007, therefore, set provisions to foster regulation, requiring that municipalities should define the agencies that would regulate their services. It also stated that these agencies could be created at the municipal, regional (by a group of municipalities) or State level. The result was that by September 2020 there were 72 WSS subnational agencies in the country: 34 municipal, 13 regional and 25 State agencies, ${ }^{12}$ covering 3,785 municipalities (out of 5,570 in the whole country), representing $77 \%$ of the Brazilian population.

These agencies present very different sizes and institutional capacities, however. While some State and regional agencies have more than 100 employees and regulate more than 300 municipalities, many municipal agencies have fewer than 10 employees. There are differences in terms of the sectors regulated as well. In a sample of 52 agencies that participated in a survey on training needs, ${ }^{13} 21$ agencies reported that they are purely WSS agencies, while 31 are multi-sector, encompassing, for example, urban transportation, energy and gas sectors, among others.

12 E. Juliatto, Panorama Das Agências Reguladoras No Brasil, ANA, Unpublished Internal Document (July 2020).

13 R.C. Marques, Consultoria Individual Para Pesquisa e Proposição De Plano De Capacitação Em Regulação No Saneamento e Trilha Formativa No Mesmo Tema, Com Avaliação Das Soluções Educacionais Já Escolhidas. Produto 2 - Coleta De Dados e Sistematização Das Informações (The World Bank ed., 2020). 
What is more, there are issues related to the governance of many of those agencies. Research published by $A B A R^{14}$ has shown that out of 31 agencies that participated, 36 out of 86 executive positions are occupied by political appointees, without a confirmation hearing from a legislative body, and they can be fired at the will of the city mayor or State governor. Some of those agencies also lack administrative and decision-making independence.

Another interesting aspect is that because there is no rule with regard to the size of the area or the region to be covered by each agency, there are cases where one water company is regulated by more than one agency (in some cases by more than four different agencies), which increases the cost of compliance with the variety of rules set by the agencies. Moreover, there is the case of overlapping regulatory agencies. Namely, in some places there are two regulatory agencies regulating the services for the same city. This happens when a municipality creates its own agency to regulate a State-owned water company that is already regulated by a State agency. In these cases, conflicts of jurisdiction arise, and the most common solution is to split responsibilities between the two agencies: while the State agency performs economic regulation, setting the tariffs, for example, the municipal agency stays in charge of monitoring the quality of the services.

Table 5. Distribution of regulatory agencies by type

\begin{tabular}{|l|c|c|c|c|}
\hline $\begin{array}{c}\text { Type } \\
\text { of Regulatory } \\
\text { Agency (RA) }\end{array}$ & $\begin{array}{c}\text { Number } \\
\text { of Municipalities } \\
\text { Served }\end{array}$ & $\%$ & $\begin{array}{c}\text { Population } \\
\text { 2018 (per million } \\
\text { inhabitants) }\end{array}$ & $\%$ \\
\hline municipal & 31 & 0.6 & 23.9 & 13.6 \\
\hline inter-municipal & 350 & 6.3 & 13.3 & 7.5 \\
\hline State & 3,350 & 60.1 & 96.7 & 54.8 \\
\hline more than 1 RA & 54 & 1 & 2.4 & 1.4 \\
\hline without RA & 1,785 & 32 & 40.1 & 22.7 \\
\hline
\end{tabular}

Source: Juliatto (2020)

The result of this combination of a large number of agencies, diverse institutional capacities, lack of good governance and overlapping jurisdiction is a fragmented regulation and an increased perception, by investors, of the regulatory risk of the water and sanitation services sector in Brazil.

In this context, in 2016, during the initial discussions of the new WSS Law in the Office of the President, policymakers proposed to create a new regulatory agency

14 Associação Brasileira De Agências De Regulação (ABAR), Coletânea Regulação do Saneamento Básico 2019 (2019) (Apr. 15, 2021), available at https://abar.org.br/mdocs-posts/coletanea-regulacao-dosaneamento-basico-2019/. 
at the federal level aimed at harmonizing the regulation of the WSS sector. This idea did not go forward because of fear that the creation of a new agency would have a negative public perception. The alternative was to empower an already-existing federal agency, at that time named the National Water Agency, to perform regulatory oversight of the WSS sector in Brazil.

\subsection{Brazil's National Water and Sanitation Agency (ANA, in the Portuguese Acronym)}

ANA was created in 2000, at the time named the National Water Agency. It had the main responsibility to implement the National Water Resources Policy at the federal level. Its main roles, at the time of its creation, were:

- hydrological monitoring;

- granting water rights at federal rivers; ${ }^{15}$

- charging for raw water withdrawal and effluent disposal at federal rivers;

- formulation of Water Resources Master Plans;

- classification of water bodies according to their uses;

- development and Implementation of the National Water Resources Information System;

- capacity-building of the institutions that constitute the National Water Resources Framework.

Differently from many countries that usually regulate water resources and water and sanitation services through a single agency, in Brazil, at the time of ANA's creation, the view was that the WSS sector was one of the users of water resources, such as irrigation, industry and hydroelectricity, and, as such, they should be treated equally. Besides, the Federal Government has no jurisdiction over the provision and regulation of water and sanitation services.

In 2009, ANA received a new competence: to perform economic regulation of raw water services, comprising a large Inter Basin Water Transfer Project, which was aimed at providing water for more than 12 million people in four States in the Northeast Region, and public irrigation projects.

Two years later, in 2010, the Parliament assigned to ANA the responsibility to regulate dam safety at the federal level. At that time this was a huge challenge, because Brazil, although recognized for its large dams that made clean energy possible in the country, did not have a legal and regulatory framework for dam safety.

Finally, in July 2020, Law 14.026/2020 expanded considerably ANA's competencies, incorporating the role of regulatory oversight of the WSS sector in the country. The

15 In Brazil, there are two jurisdictions over water resources: Federal and State jurisdiction. The Federal Government has jurisdiction over surface waters (rivers or lakes) that cross more than one State or serve as a boundary between States or between Brazil and other countries. States have jurisdiction over rivers and lakes confined to their limits, and over groundwater. 
law also changed the name of the agency, from National Water Agency to National Water and Sanitation Agency.

The key roles given to ANA from this new law can be grouped into three major duties:

1. to write standard guidelines for the regulation of the WSS sector at the subnational level;

2. to provide training and capacity-building of WSS subnational regulators;

3. to dispense mediation and arbitration of conflicts involving water utilities, municipalities and regulatory agencies.

The first principal mandate, to write standard guidelines, aims to harmonize regulation of the WSS sector in Brazil. As already earlier, there are more than seventy regulatory agencies, each one writing its own regulations, increasing the perception of regulatory risks due to differing interpretations of legal provisions as well as the costs of compliance. The law specifically stated the subjects to be addressed by the standard guidelines. They are:

I- quality and efficiency standards in the provision, maintenance and operation of WSS;

II - tariffs regulation of WSS, aiming to promote adequate provision, rational use of natural resources, the economic and financial equilibrium of the service provider, and universal access to services;

III - standardization of legal instruments for the provision of WWS signed between the granting authority of the public service and the service provider, which will include quality, efficiency and expansion of service coverage goals, as well as the proper allocation of risks and mechanisms to maintain the economic and financial equilibrium of activities;

IV - goals for universal access to WSS that include, among other conditions, the level of existing service coverage, the economic and financial viability of expanding service provision and the number of municipalities served;

$\mathrm{V}$ - criteria for accounting regulation;

$\mathrm{VI}$ - progressive reduction and control of water losses;

$\mathrm{VII}$ - a methodology for calculating indemnities due to investments made and not yet amortized or depreciated;

VIII - governance of regulatory agencies, following the principles established in article 21 of Law 11.445, of 5 January 2007;

IX - reuse of treated sanitary effluents, in accordance with environmental and public health standards;

$\mathrm{X}$ - parameters to determine administrative proceedings of forfeiture in the provision of basic public sanitation services;

$\mathrm{XI}$ - standards and goals for replacing the combined sewers system with sanitary systems;

XII - system for assessing the meeting of goals for expansion and universal coverage of WSS; 
XIII - minimum content for the universal provision and the economic and financial sustainability of WSS.

One important aspect of this role is that, as stated previously, the Federal Government does not have jurisdiction over the WSS sector. Therefore, these standard guidelines for regulation are not mandatory. They need to be transposed into regulations by the subnational regulatory agencies to become compulsory. In order to incentivize those agencies to adopt the standard guidelines, the Federal Government made use of its "spending powers." In other words, municipalities will only have access to federal funding for WSS if they choose a regulatory agency that adopts ANA's guidelines. ANA shall, therefore, monitor the adoption of those standard guidelines and disclose the names of the agencies that do not adopt them.

The second principal mandate assigned to ANA is the capacity-building of subnational WSS regulatory agencies. A study carried out by Marques, ${ }^{16}$ on behalf of ANA, pointed out the need for training of most of those agencies and identified the main knowledge gaps in those agencies. Among the most important subjects that need to be addressed to improve the technical capacity of the agencies, the study pointed out economic and contractual regulation. It also shows that executive officers and board members usually do not receive adequate training for those positions.

Finally, the third principal mandate given to ANA is the role of being the agency to offer mediation and arbitration of conflicts involving municipalities, regulatory agencies and water companies. In these cases, all the parties need to agree to submit the conflict to ANA for resolution. This role is an attempt to reduce litigations at judicial courts as well as to reduce the risks of a decision being made by someone who is not technically equipped to deal with regulatory issues.

These mandates constitute a major challenge to ANA. While capacity-building is an activity that ANA has been conducting for the past twenty years, writing standard guidelines and performing mediation and arbitration are new to the agency.

In the case of standard guidelines, this is a new approach in the context of infrastructure services and their regulation in Brazil. There is no other regulatory oversight body in Brazil and ANA, when writing down its regulations, needs to reconcile the harmonization of regulation with local and regional characteristics. Brazil is a huge country, with more than 8.5 million $\mathrm{km}^{2}{ }^{2}$ Therefore, there are different aspects that influence the provision of services that should be considered when writing down the guidelines. For example: climate, water availability, population density, urbanization, income per capita, and others.

One final topic of discussion is the regulatory oversight role of ANA. The Organisation for Economic Co-operation and Development (OECD) ${ }^{17}$ defines regulatory

16 Marques, supra note 13.

17 OECD, Recommendation of the Council on Regulatory Policy and Governance (2012) (Apr. 15, 2021), available at https://www.oecd-ilibrary.org/governance/recommendation-of-the-council-onregulatory-policy-and-governance_9789264209022-en. 
oversight as "the variety of functions and tasks carried out by bodies/entities in the executive or at arm's length from the government in order to promote highquality evidence-based regulatory decision making." OECD also lists the functions that need to be carried out to be considered regulatory oversight. These functions are organized in five areas, as presented in Table 6 below.

Table 6. Functions of Regulatory Oversight according to OECD

\begin{tabular}{|c|c|}
\hline $\begin{array}{l}\text { Areas of Regulatory } \\
\text { Oversight }\end{array}$ & Key Functions \\
\hline $\begin{array}{l}\text { Quality control } \\
\text { (scrutiny of the } \\
\text { process) }\end{array}$ & $\begin{array}{l}\text { - Monitor adequate compliance with guidelines/set } \\
\text { processes } \\
\text { - Review legal quality } \\
\text { - Scrutinize impact assessments } \\
\text { - Scrutinize the use of regulatory management tools and } \\
\text { challenge if deemed unsatisfactory }\end{array}$ \\
\hline $\begin{array}{l}\text { Identifying areas } \\
\text { of policy where } \\
\text { regulation can be } \\
\text { made more effective } \\
\text { (scrutiny of substance) }\end{array}$ & $\begin{array}{l}\text { - Gather opinions from stakeholders on areas in which } \\
\text { regulatory costs are excessive and/or regulations fail to } \\
\text { achieve its objectives. } \\
\text { - Reviews of regulations and regulatory stock. } \\
\text { - Advocate for particular areas of reform }\end{array}$ \\
\hline $\begin{array}{l}\text { Systematic } \\
\text { improvement of } \\
\text { regulatory policy } \\
\text { (scrutiny of the } \\
\text { system) }\end{array}$ & $\begin{array}{l}\text { - Propose changes to improve the regulatory } \\
\text { governance framework } \\
\text { - Institutional relations, e.g. cooperation with } \\
\text { international institutions for coordination with other } \\
\text { oversight bodies } \\
\text { - Monitoring and reporting, including report progress } \\
\text { to parliament/government to help track success of the } \\
\text { implementation of regulatory policy }\end{array}$ \\
\hline $\begin{array}{l}\text { Coordination } \\
\text { (coherence of the } \\
\text { approach in the } \\
\text { administration) }\end{array}$ & $\begin{array}{l}\text { - Promote a whole of government, coordinated } \\
\text { approach to regulatory quality } \\
\text { - Encourage the smooth adoption of the different } \\
\text { aspects of regulatory policy at every stage of the policy } \\
\text { cycle } \\
\text { - Facilitate and ensure internal coordination across } \\
\text { ministries/departments in the application of regulatory } \\
\text { management tools }\end{array}$ \\
\hline $\begin{array}{l}\text { Guidance, advice, } \\
\text { and support } \\
\text { (capacity-building in } \\
\text { the administration) }\end{array}$ & $\begin{array}{l}\text { - Issue guidelines and guidance } \\
\text { - Provide assistance and training to regulators/ } \\
\text { administrations for managing regulatory policy tools } \\
\text { (i.e. impact assessments and stakeholder engagement) }\end{array}$ \\
\hline
\end{tabular}


At the beginning of the discussions on the new law in the Office of the President in 2016, the role of ANA was thought to be the regulatory oversight of the water and sanitation services in Brazil. However, during the discussions in the Parliament, some of ANA's roles were changed and not all the functions were assigned either to ANA or to any government body. When comparing the roles assigned to ANA with the functions defined by OECD, it becomes clear that not all the functions will be performed by the agency:

- Quality Control (scrutiny of the process): ANA will not perform quality control of regulations issued by subnational agencies, but will verify whether subnational agencies adopt the regulations issued by ANA or write up new regulations that are coherent with ANA's ones. On the other hand, ANA will have to perform Regulatory Impact Analysis - RIA of all of its new regulations, assessing the impacts on the whole country. (To date, RIA is performed only by a few subnational agencies.)

- Identification of areas of policy where regulation can be more effective (scrutiny of substance): According to Law 14.026/2020, ANA can only propose new regulation on the subjects explicitly stated in the law.

- Systematic improvement of regulatory policy (scrutiny of the system): ANA will carry out institutional relations and monitoring and reporting to track the success of the implementation of regulatory policy.

- Coordination (coherence of the approach in the administration): ANA will promote a coordinated approach to WSS regulatory quality, encourage the smooth adoption of the different aspects of regulatory policy at every stage of the policy cycle and it is expected that ANA will help to facilitate and ensure internal coordination across ministries/departments in the application of regulatory management tools.

- Guidance, advice and support (capacity-building in the administration): ANA will issue standard guidelines and guidance and will provide training to regulators/ administrations for managing regulatory policy tools.

Having presented the context of the water and sanitation services in Brazil and the changes brought about by the new legislation, the next item will discuss the strengths and weaknesses of this new framework.

\section{Is That Going to Work? \\ A Critical Analysis of the WSS Sector Reform}

The reform brought about by Law $14.026 / 2020$ represents far-reaching changes in the WSS sector in Brazil. In the previous model, most of the services were provided by State-owned water companies, most of them currently being in difficult financial situations. The reform, therefore, aims to foster private capital to promote the investments necessary to reach universal access to the services.

In summary, the new provisions set by Law $14.026 / 2020$ were: (1) to define clear goals for the provision of the services; (2) to promote private participation in 
the provision of services; (3) to incentivize regionalization, aiming at economies of scale, and (4) to improve regulation. While these provisions have important roles within a larger objective of improving the WSS performance, each one presents its own challenges to reaching the expected results. These challenges will now be addressed.

The first challenge is related to the goals. As presented earlier, the law sets out that, by 2033 , coverage of water supply shall reach the goal of $99 \%$ of the population, while coverage of sewage collection and treatment shall reach $90 \%$ of the population. The National Water and Sanitation Plan (PLANSAB) (Brazil, 2019) ${ }^{18}$ estimates that to reach those goals a total investment of about BRL 600 billion (about USD 120 billion, considering an exchange rate of $1 \mathrm{USD}=5 \mathrm{BRL}$ ) would be necessary. This would mean an average annual investment of BRL 40 billion by 2033. This is a huge amount when compared to the average annual investment made between 2003 and 2017, of about BRL 5.5 billion, with a maximum of BRL 11.5 billion in 2013.

Currently, fiscal constraints in the country will not allow such a level of investment. Therefore, it is necessary to provide the conditions for increasing private-sector participation. Additionally, to improve the business environment, which will be addressed shortly, the country needs to design and implement concession projects. However, there is also a limited capacity to properly design them. Concession contracts usually take more than two years to design and obtain all the government approvals prior to the auction and signature of the contract. The Federal Government has its own Public-Private Partnerships office and presently (February 2021) there are ten projects in its WSS sector pipeline (BRASIL, 2021). ${ }^{19}$ BNDES, the Brazilian Development Bank, also designs concessions, and its pipeline currently encompasses ten projects. These two pipelines represent $4.7 \%$ of the municipalities of the country and $14 \%$ of the population. States and municipalities also have the authority to grant concessions, but their pipelines also make up a small portion of the population, and usually, municipalities do not have the technical capacity to design a concession contract adequately.

On the other hand, when comparing the completion time of projects and the amount invested by the private sector with those from the public sector in Brazil, it is possible to see the comparative advantages of the private sector in the country. A study carried out by Fundação Getulio Vargas in 2016 pointed out that public projects have, on average, a longer completion time compared to projects carried out by the private sector. While in the private sector, after six years from their

18 Secretaria Nacional de Saneamento, PLANSAB - Plano Nacional De Saneamento Básico, Documento Em Revisão Submetido à Apreciação Dos Conselhos Nacionais De Saúde (2019) (Apr. 15, 2021), available at https://antigo.mdr.gov.br/images/stories/ArquivosSDRU/ArquivosPDF/Versao_Conselhos_ Resolução_Alta_-_Capa_Atualizada.pdf.

19 BNDES Hub de Projetos, BNDES (Apr. 15, 2021), available at https://hubdeprojetos.bndes.gov.br/pt/ index.html?setor=saneamento. 
initiation, $100 \%$ of projects have been completed; after the same period only $16 \%$ of public projects were completed. Also, data from $\mathrm{ABCON}^{20}$ show that the investment made by private operators corresponds to $21 \%$ of the total invested in the country, although they only operate $5.2 \%$ of the municipalities.

Therefore, the authors of this paper believe that coverage rates will increase at larger rates, but it is unlikely that the goals stated by the law will be reached. An amendment to the law will probably be made before the 2033 deadline to adjust either the goals or the deadline itself.

The second challenge connected to the provisions set by Law 14.026/2020 is the incentive to private participation in the WSS sector. Private investors assess the risks in the business environment before making an investment decision. The law correctly addresses one of those main risks, the regulatory one. However, a major risk related to the Brazilian political environment is still at play.

A recent case in an urban road in Rio de Janeiro illustrates the issue. In brief, the Mayor of Rio de Janeiro decided to unilaterally terminate the concession contract of Linha Amarela, a seventeen-kilometer-long urban road that connects the west region to the north region of the city, alleging public interest. On 27 October 2019, the mayor ordered the city's bulldozers to destroy the toll plazas and allow vehicles to pass without paying the tolls. The mayor alleged that the concessionaire had earned excessive profits and that the population of Rio de Janeiro had already paid more than the fair amount for many years. The mayor also claimed that there was no need to pay indemnity to the concessionaire because those "large profits" were already sufficient compensation. That decision required the passage of a law from the City Hall to be confirmed, and the municipal lawmakers agreed with the mayor's proposition. The concessionaire appealed to the higher courts and, at the time this paper is being written, there is a provisional decision favoring the City of Rio de Janeiro.

This case exemplifies the sort of risk that may diminish the interest of private operators to invest in Brazil. The possibility of a municipality deploying its bulldozers to destroy the gates of the toll plaza before the proper legal proceedings have even begun may discourage foreign investment in the country. Because of this sort of risk, in the short term, it is more likely that only those operators that are from Brazil, or already have experience in the Brazilian context, will bid on the WSS concession auctions, thus reducing competition.

The third challenge is the creation of regional companies to provide the services. As explained before, the rationale behind this policy is that water and sanitation services benefit from economies of scale. Therefore, the policy is to group the municipalities into regions that will make the provision of services more feasible. However, to implement this policy, there are two main issues.

20 Panorama Da Participação Privada No Saneamento 2020, Abcon Sindcon (2020) (Apr. 15, 2021), available at https://www.abconsindcon.com.br/panoramas/. 
Firstly, State Governments have "to split" their State water companies to fit WSS regions that will provide the services under concession contracts. This will probably face political opposition from some States and the trade unions of the State water companies. The second issue is how to incorporate municipal water services into these new regional companies. Historically, cities have had their services provided by their own company or municipal department. Under normal circumstances, cities would not have the incentives to join the regional company. The incentives brought about by the new law are to prevent the municipalities from having access to federal funds if they do not join the regional companies. In Brazil, Federal Government grants and loans from federal public banks are the main sources of funding to the sector.

This strategy, to restrict access to federal funds for water and sanitation services so as to enforce the legislation has already been tried before, and its results were unsatisfactory. In 2010, Presidential Decree 7.217/2010 imposed a deadline of December 2013 for all the municipalities to elaborate their Municipal WSS Plan in order to get access to federal funds to the sector. As the municipalities were unable to comply with this deadline, it has been postponed four times by different presidential decrees. The most recent one, issued in January 2020, postponed the deadline to 31 December 2022. In fact, in 2017, ten years after the approval of Law 11.445/2007, only $30 \%$ of municipalities had elaborated their WSS $\mathrm{Plan}^{21}$ and it will likely need to be postponed again. In the current case, the legal document restricting access to federal funds is a federal law, which is stronger than a presidential decree. However, it would not be a surprise if some municipalities do not join the regional company, betting on the amendment of the law in the future.

Finally, the final challenge is to improve the regulation of the WSS in Brazil. As mentioned previously, ANA has no enforcement powers to guarantee that its guidelines will be adopted by subnational agencies. To overcome this issue, the Federal Government is adopting the same policy as in the creation of regional companies: providing funding to service providers contingent upon the adoption of ANA's standard guidelines by the respective regulatory agency. In this case, it is indirect enforcement, because the restrictions to federal funding will apply to the service provider, and not to the regulatory agency that does not adopt ANA's guidelines. In Brazil, it is the municipality that chooses its regulatory agency. This mechanism, therefore, incentivizes the municipalities to choose the regulatory agency that adopts ANA's guidelines if they do not want to jeopardize their services.

Another aspect related to the role of ANA to improve regulation is to build its legitimacy. Until 2020, ANA was not part of the WSS framework. Its role as the federal water resources agency had some interfaces with the WSS sector, mostly when granting water rights to the water utilities. However, ANA did not have any relationship with subnational WSS regulatory agencies. When the new legislation was discussed in the Parliament, subnational agencies lobbied against ANA's new

$21 \quad$ Trata Brasil, supra note 10. 
roles, as they were afraid of losing their regulatory powers. Therefore, in order to have its guidelines adopted, ANA has to build trust among the agencies, making clear that it is not taking over their regulatory powers. Instead, ANA has to show that it aims to improve the regulatory environment and capacity, which the agencies will benefit from the most. In other words, ANA will need to exercise its "soft power" with the agencies to implement the provisions set out by Law 14.026/2020.

\section{Conclusion}

Despite advances in recent decades, the water and sanitation services sector is the last major Brazilian infrastructure sector that has not been universalized in Brazil, unlike other sectors such as energy and telecommunications.

The major landmark for the development of the sector in Brazil was PLANASA The National Water and Sanitation Plan in the 1970s. It was a national policy and aimed at promoting WSS on a large scale, encouraging the creation of State-owned water companies. As a result, each State in Brazil had its own water company, responsible for the provision of services in a large part of its territory. PLANASA also created an administrative and financial structure centralized at the National Housing Bank, which was responsible for setting up tariffs for the State-owned water companies.

The dissolution of the National Housing Bank in 1985, in the context of the country's fiscal crisis of that decade, marked the stagnation of WSS policies in Brazil and the termination of PLANASA. This situation only began to reverse with the publication of Law 11.445/2007, which instituted the (past) legal framework for water and sanitation services in the country. This law brought about important advances, such as the clear separation of the different roles played by the various actors: planning, regulation and service-provision activities.

Nevertheless, the figures for WSS coverage remain far from ideal and the country has to deal with a very fragmented institutional arrangement, driven by municipal ownership of the services and the consequent dispersion of regulation. This situation creates obstacles to the promotion of the necessary regulatory and legal stability.

Another major obstacle for the sector has been the municipalities' ability to sign public/public contracts with State-owned water companies without a competitive process, thus creating a barrier to entry for the private sector.

These are the challenges that the reform of the sector, through Law 14.026/2020, intends to address by standardizing regulation and contracts, promoting regulatory effectiveness, regionalization and fostering competition in the provision of services. The reform has the objective of providing more legal certainty, uniform rules and better regulatory governance to attract investments to the sector, as seen in the four pillars of the new legal framework: improvements in the regulatory framework; regionalization of the services provision; standardization of services provision contracts; and removal of barriers to entry to the private sector.

Concerning regulation, the large number of subnational WSS regulatory agencies, with different sizes and institutional capacities, each one with its own set of regulations 
and procedures, is highlighted. In this context, the reform of the sector empowered the role of ANA to write standard guidelines for the regulation of the WSS sector at the subnational level; to provide training and capacity-building of WSS subnational regulators; and to dispense mediation and arbitration of conflicts involving water utilities, municipalities and regulatory agencies.

The implementation of the provisions of the law will be a huge challenge for the country. It is emphasized that, based on experience, it will be very difficult for the country to reach the universalization goals by 2033, mainly due to the amount of investments required and the political risks in the country. Additionally, the mechanism of enforcement of the law is an indirect one, taking advantage of the "spending powers" of the Federal Government, restricting the access to federal funds to those municipalities that do not adopt the provisions of the law. It has been shown that previous experience with this type of strategy was not successful, but, in the current case, the authors of this paper believe that it is more likely to succeed because the restriction is based on federal law.

Although not free from criticism, the new milestone has the potential to change the WSS panorama towards universal service in Brazil and the authors believe that the reform will promote the investments necessary to reach universalization, but it is very unlikely that those goals will be achieved by 2033 .

\section{References}

O Futuro do Brasil (Fabio Giambiagi ed., 2021).

Sampaio P.R.P. \& Sampaio R.S.R. The Challenges of Regulating Water and Sanitation Tariffs Under a Three-Level Shared-Authority Federalism Model: The Case of Brazil, 64 Util. Pol'y 101049 (2020). https://doi.org/10.1016/j.jup.2020.101049

\section{Information about the authors}

Carlos Motta Nunes (Brasília, Brazil) - Executive Manager, Water and Sanitation Task Force, Brazil's National Water Agency (SPO Área 5, Quadra 3, Brasilia, 70.610-200, Brazil; e-mail: carlos.motta@ana.gov.br).

Alexandre Anderaos (Brasília, Brazil) - Water Resources and Sanitation Specialist, Water and Sanitation Task Force, Brazil's National Water Agency (SPO Área 5, Quadra 3, Brasilia, 70.610-200, Brazil; e-mail: alexandre.anderaos@ana.gov.br).

Cintia Leal Marinho de Araujo (Brasília, Brazil) - Director's Advisor, Directorate of Hydrology, Brazil's National Water Agency (SPO Área 5, Quadra 3, Brasilia, 70.610200, Brazil; e-mail: cintia.araujo@ana.gov.br). 